\title{
COMPETITIVE STRATEGY AS THE ALTERNATIVE LONG-TERM POLICY IN MANAGING CONSUMER CREDIT: A CASE STUDY ON GLOBAL CONSUMER GROUP OF CITIBANK INDONESIA
}

\author{
Fariz \\ STIE YAPAN Surabaya, Indonesia \\ E-mail: fariz@stieyapan.ac.id
}

\begin{abstract}
Several big scale banks in Indonesia show quite high consumers credit growth. This will make the competition between banks in Indonesia to be tighter. Based on the research background that has been previously mentioned, it can be decided that the goal of the research is to analyze the appropriate competitive strategy on the Global Consumer Group (GCG) of Citibank Indonesia in managing consumers credit as the long-term policy alternative in order to win the competition seeing from the internal environment analysis or external environment analysis with explanatory "case study" type of research. Based on the processing, testing, and discussion of the research results related to the problem, here are the conclusion and suggestion that can be taken considering its existing relationship with the research: Key factors to success in the banking industry are: a wide range of network, strategic location, good service, and aggressive marketing. Based on the SWOT analysis, Citibank Indonesia can be said to be able to respond using appropriate strategy by expanding distribution network (branch and partnership), creating a local image through various products, creating product and service that are suitable for all members, educating the community on the product and service they produce. The research results are only applicable to the research object of Global Consumer Group (GCG) Citibank Indonesia. Thus, the similarity cannot be guaranteed if it is applied to other objects. The results cannot be generated case by case where there is no previous research especially in the Consumer Group section on the Banking industry.
\end{abstract}

\section{KEY WORDS}

Competitive strategy, environment analysis, external environment analysis, SWOT analysis.

Citi Indonesia was closed with satisfying financial performance during 2016-2017 despite local and global economic challenges. Its branches in Indonesia keep improving its financial performance and generating satisfying results. This shows the balance and strong market improvement in the corporate, commercial, investment, and consumer banking fields through the improvement of the retail bank, credit card, Citifinancial, and Personal Loan segments in which consumer banking segment had an important role according to the annual report (Annual Report, 2017).

Citi provides various advanced solutions for consumers compared to the local competitors. Citibank business has reached satisfying growth due to its strong position and innovation of new products. City focuses themselves on the costumers' needs and the superiority in maintaining the relationship with the consumers who have helped them to realize the Citibank's purpose to be the number one in every product category to do business as well as being well-known as the most professional and trusted advisor for the consumers.

GCG is the pioneer in the credit card industry in Indonesia. One of the main pillars of the credit sector is credit card service which is more common to be used in the big cities in Indonesia. Citibank Indonesia keeps creating innovative programs and adding value to the consumers. Citi will keep strengthening its existing position and being in the front of every competitor and/or market through various ways such as offering innovative products, better market segmentation to get appropriate consumer, develop the cooperation, expanding the coverage area as well as increasing the analysis data to strengthen the consumers' acquisition. Credit card business keeps growing and dominating the market by $33 \%$ of the 
market segment on the credit card transaction in Indonesia. Citi Credit Card will always be the most remembered brand and being in the top position for the Indonesian consumers because of their innovator product features, safety, and convenience in doing the transaction, other benefits such as protection toward the product they have bought and special consumer service.

Citibank Indonesia Global Consumer Group (CGC) is specifically demanded to keep renewing themselves by formulating proper strategy, considering that government banks such as BRI, Mandiri or other private banks such as BCA can be their serious competitor. Several big scale banks in Indonesia show quite high consumers credit growth. Some of the considerations for the bank to keep focusing on the consumers' credit are high yield, risk diversified on many debtors, relatively simple credit process, relatively small exposure, guarantee (second way out) that tends to be appreciated (property). In addition, several national private banking and the foreign bank have relatively similar excellence products.

This will make the competition between banks in Indonesia to be tighter. Globalization has changed limiting stuff to be unstoppable free one. Every company will easily obtain the resources they want anytime and anywhere it exists. In the next development, the company will compete at the global competition and they have to have a competitive advantage. According to Swierz and Spencer (2002), competitive advantage is a unique position developed by an organization as an effort to defeat the competitor.

Other than observing various external environments, Citibank Indonesia should also observe the internal environment. By observing how big the impact of the global tendency for a global industry, Citibank Indonesia needs to analyze what will be the strength and weakness as well as the threat and opportunity they can achieve. It is suggested to reduce or eliminate the weakness while keep improving the strength. It is expected internal strength will help to achieve the existing opportunity.

Based on the research background that has been previously stated, the research problem can be formulated as "How appropriate competitive strategy on the Global Consumer Group (GCG) Citibank Indonesia in managing consumers credit as the long-term policy alternative to win the competition seeing from both internal and external environments?" the research purpose can also be determined as analyzing the appropriate competitive strategy on the Global Consumer Group (GCG) Citibank Indonesia in managing consumers credit as the long-term policy alternative to win the competition seeing from both internal and external environments.

\section{LITERATURE REVIEW}

The concept of competitive strategy. According to Maulana (2005), competitive strategy is a combination between ending (goal) that has been fought by the company with the tool (policy) where the company tries to get there and every company has different terms for several described concepts. The strategy is greatly needed in order to overcome various critical activities from the company as well as face the future that tends to be uncertain and difficult to predict.

According to Porter (1980), there are three generic strategic approaches that can potentially able to surpass other companies in the industry, they are:

Overall cost leadership. Having a low-cost position will make the company to earn a profit above average in their industry despite the competitor solid strength. This also provides endurance to the rivalry of other competitors because the lower cost will be able to keep earning a profit after the competitor sacrifices their profit for the competition.

Differentiation. The company differentiates the product or service by creating something new that is perceived by the entire industry as something unique. The approaches for differentiation can be in various forms such as design image or brand, technology, service, consumers, network, distributor, or other dimensions. Ideally, the company differentiates itself in several dimensions.

Focus. It focuses on the buyer group, products line segment, or specific market geographic. Focus strategy is built to serve a certain target well and all functional policies are 
developed on the basis of thought that the company will be able to serve its limited strategic target effectively and efficiently comparing to the competitor at the wider target.

SWOT Analysis. According to Rangkuti (1997), SWOT analysis is the analysis of strength and weakness of the organization. The analysis is carried out through the study on the internal condition of the organization as well as the analysis on the opportunity and threat faced by the organization that is carried out through the study on the external condition of the organization. A SWOT analysis will only be useful when it has been clearly determined in what business the company will operate and in which direction the company will go in the future as well as what measures will be used to assess the success of the organization/management in running its mission and realizing its vision. SWOT analysis emphasizes the fundamental principle that strategy has to create conformity between the company's internal ability (strength and weakness) with the external situation (opportunity and threat) faced by the company.

According to Rangkuti (1997), strength is something in which a company excels in something or a company characteristic in the form of skills, organizational resources or valuable competitive capabilities, or achievements that place the company in a position to have an advantage in the market such as a good product, famous names, technological excellence or good customer service. Strength can also be the result from alliance or cooperation with a partner who has skills or ability that can increase a company's advantage.

A weakness is the company's shortcoming or doing something poorly comparing to the competitor or a condition that places the company in a disadvantageous situation. A weakness enables the company to be easily attacked depending on how important the weakness in the market. Based on the composition strategy, the company's strength is very important because it can be the stepping stone of the strategy and as the fundamental for creating competitive advantage. Company's strategy should be in accordance with the company's strength and ability.

According to Rangkuti (1997), the opportunity is anything that can give the possibility to the company to grow or build a competitive advantage in a competitive situation. Meanwhile, the threat is any risk from the external environment in which its reflection can affect the success of marketing strategy applied by the company (Urban \& Star; 1991). These threats can come from the competitor, economic and politic changes, acquisition, government regulations, and others. Opportunity and threat not only affect the company's situation but also indicating the needs for strategic action. In order to correspond to the company's situation, the strategy should be directed to pursue the opportunity in accordance with the company's' ability as well as providing defense for the external threat.

\section{METHODS OF RESEARCH}

According to Yin (1996), a case study is a strategy that is more appropriate if the principal research question trying to answer "how" and "why" where the research focuses on the current event requiring two other evidence sources namely observation and interview to support the ongoing research. In this research, the researcher aims to examine the causal relationship between one perspectives with other perspectives. Thus, the case study to be written will be explanatory in nature. The type of research used in this research is descriptive research by using qualitative and naturalistic approaches. The chosen method is; case study' Description research aims to give an accurate illustration of the condition on a certain symptom to determine the relationship between one symptom with other symptoms (Koentjaraningrat, 1981).

According to the author, considerations on the research selection are as follows:

- This research aims to answer the questions in the problem statement;

- The researcher cannot measure, control or affect the nature, behavior, or even the environment of the research object (Yin, 1989: 20) thus the researcher only conducted in-depth examination or observation in Global Consumer Group (GCG) Citibank Indonesia as the research object; 
- The research purpose is to analyze appropriate competitive strategy on the Global Consumer Group (GCG) Citibank Indonesia in managing consumers credit as the long-term alternative policy to win the competition seeing from both internal and external environments with all of its condition and adjustments related to the specification that may be slightly different between theory and field conditions.

Research Design. The research design of competitive strategy as the long-term policy alternative in managing consumers' credit (case study on Global Consumer Group (GCG) Citibank Indonesia) single case study has the following main steps:

- Establishing "competitive strategy on the Global Consumer Group (GCG) Citibank Indonesia" as the focus of research case;

- Literature study to be used as a theoretical framework which will be used as a framework of thinking during the research;

- Research design process and data selection especially related to the company profile as well as the support on the external and internal analysis;

- Conducting a case study;

- Implementing the strategy in the company's level, return to the theories that have been previously developed;

- Triangulating (confirmation) and discussion with management on the obstacle and finding of the issues faced in the field;

- Interpretation on research results in the form of evaluation on the company's position as well as drawing the conclusion or finding on the problem statement and giving a suggestion for the development of implementation from the research results where it can be used as strategy formulation strategy in the future.

Analysis units. Analysis unit in this research is a competitive strategy on the Global Consumer Group (GCG) Citibank Indonesia in managing consumers' credit as the long-term alternative policy to win the competition seeing from both internal and external environments. The logic that links data with research questions. Here are the explanations on the research logic with research question that have been previously formulated.

Table 1 - Data Association Logic

\begin{tabular}{|c|c|c|c|}
\hline No. & $\mathrm{RQ}$ & Relevant Data & Data Association Logic \\
\hline 1 & $\begin{array}{l}\text { How the appropriate strategy } \\
\text { competitive on the Global } \\
\text { Consumer Group (GCG) Citibank } \\
\text { Indonesia in managing consumers } \\
\text { credit as the long-term alternative } \\
\text { policy to win the competition seeing } \\
\text { from both internal and external } \\
\text { environments. }\end{array}$ & $\begin{array}{l}\text { Internal environment analysis } \\
\text { (general description of the } \\
\text { company; analysis of the } \\
\text { company's functional } \\
\text { performance consisting of } \\
\text { finance, marketing, operations, } \\
\text { HR, organization and } \\
\text { management); } \\
\text { External environment analysis } \\
\text { (Indonesian banking conditions, } \\
\text { people's purchasing power, the } \\
\text { level of competition between } \\
\text { banks) }\end{array}$ & $\begin{array}{l}\text { This description is important to } \\
\text { determine the fact that the } \\
\text { preparation of competitive } \\
\text { strategy can be used as a long- } \\
\text { term alternative policy to win the } \\
\text { competition through the analysis } \\
\text { of the external and internal } \\
\text { environment }\end{array}$ \\
\hline
\end{tabular}

Source: Processed Data (2018).

Data collection in the field was carried using these methods:

- Preliminary survey to Global Consumer Group (GCG) Citibank Indonesia as the research site; conducting interviews with the board of managers and studying documents owned by Citibank. These were carried out to obtain a general description of the condition as well as identifying the problem;

- Literature study is finding the works of literature as a theoretical framework, concept, logical reasoning that can be used to answer the occurring problems and helping the researcher in the research process;

- Field activity is research activity to gather relevant and specific data for the research purpose and problems; 
- Documentation is in the form of gathering written data owned by Global Consumer Group (GCG) Citibank Indonesia such as financial, marketing, operational, HR, organizational and management reports.

Data Analysis Technique. The overall data used in this research used secondary data. These data were obtained from the library, mass media, and the Internet. The data were then analyzed using these approaches:

Five force analysis. This analysis explains how five forces competition determines the intensity of the competition and ability in the industry. These five forces are the threat of the new newcomer, the threat of substitute products, the strength of buyer bargaining, the bargaining power of suppliers and competition among existing competitors.

SWOT Analysis. This analysis is used to find out threat and opportunity by identifying and evaluating the internal and external variables of the company. Thus, the profile of the company's strategic advantage can be seen as well as simultaneously reduce/minimize the weaknesses of the company.

Market share growth matrix (Boston Consulting Group / BCG). It is used to determine the company's product position in the market. In addition, the high-low of available business opportunity should be known by finding the growth level in the market.

\section{RESULTS AND DISCUSSION}

Based on the SWOT analysis, the company's position is in quadrant I, the management strategy of Citibank Indonesia is an intensive and growth-oriented market development strategy where growth concentration is a strategy that directs the company's resources to develop and expand the market to overcome the increasingly fierce competition.

An intensive market development strategy means trying to sell products now in a new market. The method that can be used is by expanding the geographical market through intensive promotion. In term of market growth concentration, they try to attract half/all of competitors' consumers to be the consumers of Citibank Indonesia.

According to SWOT analysis, the strategy they chose is SO strategy which is by utilizing the strength to seize the opportunity. The direction of the development strategy is to establish a partnership with investors, improve human resources and build supporting facilities in which one of the ways is by expanding the network and accelerate market penetration through a strategic partnership with top companies in the financial industry such as First State Investments, Prudential, and ATM Bersama partners.

Based on the above analysis and discussion, a Business Strategy can be formulated as the reflection of approach pattern and steps arranged by the management to achieve successful performance in one specific business line as the appropriate competitive strategy on Global Consumer Group (GCG) Citibank Indonesia in managing consumer credit where credit cards and multipurpose loans are seen as the main products as a long-term alternative policy to win competition seen from the analysis of the internal environment and the analysis of the external environment, among others:

Table 2 - Grand Strategy of Citibank Indonesia

\begin{tabular}{|c|c|}
\hline Grand Strategy (Grand Strategy) & Main Product \\
\hline $\begin{array}{l}\text { Cross-selling by giving privilege on the existing debtor, one of them is Debit Card Citibank Visa } \\
\text { that gives access to cash and facilitates shopping globally for the consumer. This is the only } \\
\text { debit card with special features such as cash rewards, point rewards, and Citibank World } \\
\text { Privileges. } \\
\text { Expanding the network and accelerating the length of time to win the competition seen from the } \\
\text { analysis of the internal and external environments include: } \\
\text { Aggressive direct marketing by adding and optimizing outlet/distribution network in improving the } \\
\text { acceleration of consumers credit where GCG has } 6 \text { branches, } 14 \text { cash offices, } 65 \text { CitiFinancial } \\
\text { offices, and } 104 \text { ATMs in six major cities in Indonesia (Jakarta, Surabaya, Bandung, Medan, } \\
\text { Semarang, and Denpasar) } \\
\text { Optimizing the IT advances in marketing the consumers' credit in which it is realized in the new } \\
\text { products such as citi mobile and citi clear card to provide various products. }\end{array}$ & $\begin{array}{l}\text { Credit Card: Increased } \\
\text { credit card portfolio is } \\
\text { focused on increasing the } \\
\text { limit on existing customers } \\
\text { rather than adding new } \\
\text { customers (net customers) } \\
\text { Multipurpose Credit: offering } \\
\text { multipurpose credit to well- } \\
\text { known costumes such as } \\
\text { gold or platinum consumers' } \\
\text { credit card with a good track } \\
\text { record. }\end{array}$ \\
\hline
\end{tabular}

Source: Author (Processed), 2018. 


\section{CONCLUSION}

Based on the processing, testing, and discussion of the research results related to the problem, here is the conclusion in the form of the grand strategy of Citibank Indonesia that can be taken considering its existing relationship with the research.

Key factors to success in the banking industry are: a wide range of network, strategic location, good service, and aggressive marketing.

Based on the SWOT analysis, Citibank Indonesia can be said to be able to respond using appropriate strategy by expanding distribution network (branch and partnership), creating a local image through various products, creating product and service that are suitable for all members, educating the community on the product and service they produce.

Grand Strategies of Citibank Indonesia are:

Cross-selling by giving privilege on the existing debtor, one of them is Debit Card Citibank Visa that gives access to cash and facilitates shopping globally for the consumer. This is the only debit card with special features such as cash rewards, point rewards, and Citibank World Privileges;

Expanding the network and accelerating the length of time to win the competition seen from the analysis of the internal and external environments;

Aggressive direct marketing by adding and optimizing outlet/distribution network in improving the acceleration of consumers credit where GCG has 6 branches, 14 cash offices, 65 CitiFinancial offices, and 104 ATMs in six major cities in Indonesia (Jakarta, Surabaya, Bandung, Medan, Semarang, and Denpasar);

Optimizing the IT advances in marketing the consumers' credit in which it is realized in the new products such as citi mobile and citi clear card to provide various products.

The suggestions that can be given are:

- Improving the image of Citibank Indonesia as a trusted bank so that people can be more interested to invest their fund. Therefore, Citibank Indonesia has to put the effort in the ways of giving better and various credit, creating new interesting credits as well as searching and developing potential consumers;

- Improving the skills of administrators and employees by following the advancement of existing banking technology. The efforts that have been carried out are in line with the improvement of professionalism from the Citibank Indonesia itself.

\section{REFERENCES}

1. Arthur, J., Thompson, Jr., \& Strickland, A. J. (1998). Strategic Management: Concepts and Cases (10th Ed). England: McGraw-Hill Inc.

2. Bank Indonesia. (1999). Studi Ekonomi Bantuan Likuiditas Bank Indonesia. Jakarta: Bank Indonesia.

3. Fariz, F. (2014). Analisis Orientasi Pasar Kearah Keunggulan Kinerja Rumah Sakit Di Kota Dan Kabupaten Malang. Orasi Bisnis, 12(2), 54-62.

4. Fariz, F. (2015). Pengaruh Iklim Organisasi Terhadap Kepuasan Kerja Karyawan Pada Pt. Jasamitra Propertindo. Orasi Bisnis, 14(2), 35-43.

5. Fuld, L. M. (1994). The New Competitor Intelligence: The Complete Resources for Finding, Analyzing and Using Information about Your Competitors. USA: John Wiley and Sons, Inc.

6. Hamel, G., \& Prahalad, C. K. (1994) Competing for The Future. USA: Harvard Business School Press Boston, Massachusetts.

7. Jain, C.S. (1990), Marketing Planning and Strategy. USA: South Western Publishing, Co.

8. Kotler, P. (1990), Marketing Management:Analysis, Planning, Implementation and Control (8th Ed). England: Prentice Hall International, Inc.,

9. Laporan Tahunan Citibank Indonesia, 2017.

10. Laporan Tahunan Citibank Indonesia, 2018.

11. Porter, M. E. (1985). Competitive Advantage. Canada: The Free Press-Collier Macmillan Canada. 
12. David, F. R. (1997). Strategic Management (6th Ed). New Jersey: Prentice Hall Inc.

13. Rangkuty, F. (1999). Analisis SWOT Teknik Membedah Kasus Bisnis: Reorientasi Konsep Perencanaan Strategis untuk Menghadapi Abad 21. Jakarta: PT. Gramedia Pustaka Utama Jakarta.

14. Thompson, A. A., \& Strickland, A. J. (1992), Strategic Management Concepts and Case. Illinois: Homewood.

15. Tjiptono, F. (1995). Strategi Pemasaran. Yogyakarta: Andy Offset.

16. Urban, G. L., \& Star, S. H. (1991). Advance Marketing Strategy: Phenomena, Analysis and Decisions. New Jersey: Prentice Hall International, Inc. 